\title{
Baldcypress Swamp Management and Climate Change
}

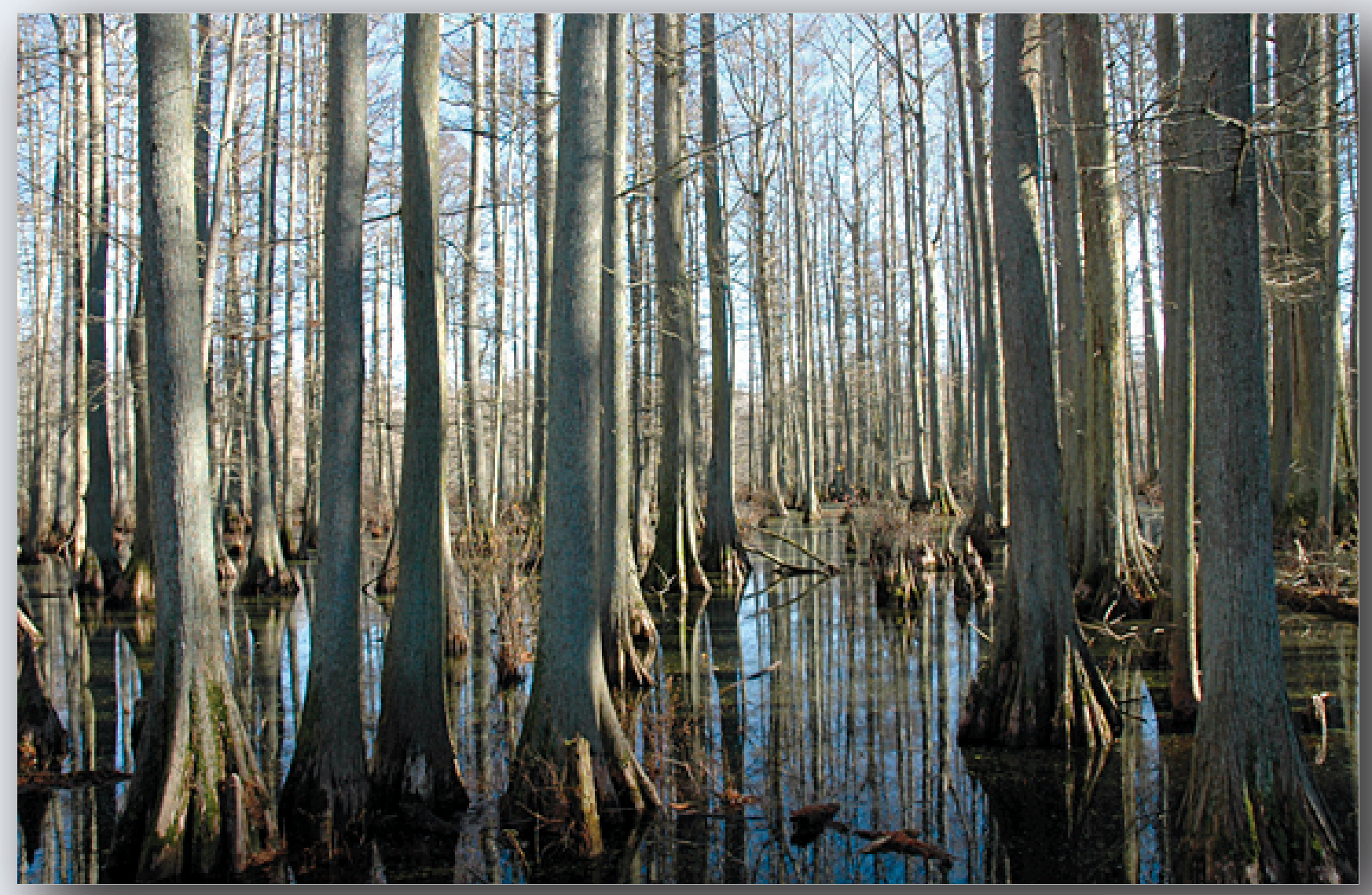

Open-File Report 2006-1269 


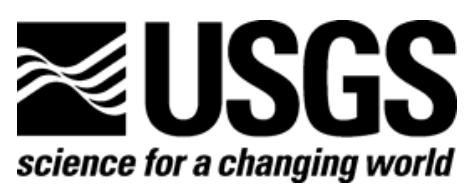

\title{
Baldcypress Swamp Management and Climate Change
}

By Beth A. Middleton

Open-File Report 2006-1269

\author{
U.S. Department of the Interior \\ U.S. Geological Survey
}




\title{
U.S. Department of the Interior DIRK KEMPTHORNE, Secretary
}

\author{
U.S. Geological Survey \\ P. Patrick Leahy, Acting Director
}

U.S. Geological Survey, Reston, Virginia 2006

For product and ordering information:

World Wide Web: http://www.usgs.gov/pubprod

Telephone: 1-888-ASK-USGS

For more information on the USGS - the Federal source for science about the Earth, its natural and living resources, natural hazards, and the environment:

World Wide Web: http://www.usgs.gov

Telephone: 1-888-ASK-USGS

Suggested citation:

Middleton, B.A., 2006, Baldcypress swamp management and climate change: U.S. Geological Survey Open-File Report 2006-1269, 3 p.

Any use of trade, product, or firm names is for descriptive purposes only and does not imply endorsement by the U.S. Government. 


\section{Contents}

Baldcypress Swamp Management and Climate Change …........................................................................ 1

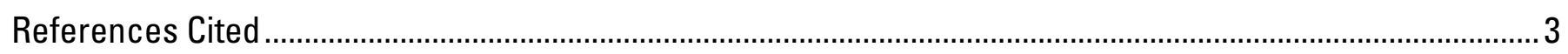

Figures

1. Total litterfall rates in baldcypress (Taxodium distichum ) swamps at various latitudes............................... 1

2. Overcup oak (Quercus lyrata) dispersing in the water................................................................................ 


\title{
Baldcypress Swamp Management and Climate Change
}

\author{
By Beth A. Middleton ${ }^{1}$
}

In the future, climates may become warmer and drier in the southeastern United States; as a result, the range of baldcypress (Taxodium distichum) swamps may shrink. Managers of baldcypress swamps at the southern edge of the range may face special challenges in attempting to preserve these swamp habitats in the future if climates become warmer and drier. Climate warming and drying would likely result in the loss of some southern populations of baldcypress swamps, and the populations most vulnerable are in Texas (Middleton and McKee, 2004) and south Florida (Crumpacker and others, 2001). Near the edge of the range of baldcypress swamps, leaf litter production is lower (fig. 1; Middleton and McKee, 2004), and tree regeneration is poorer (Middleton, unpublished data), indicating stressed growing conditions.

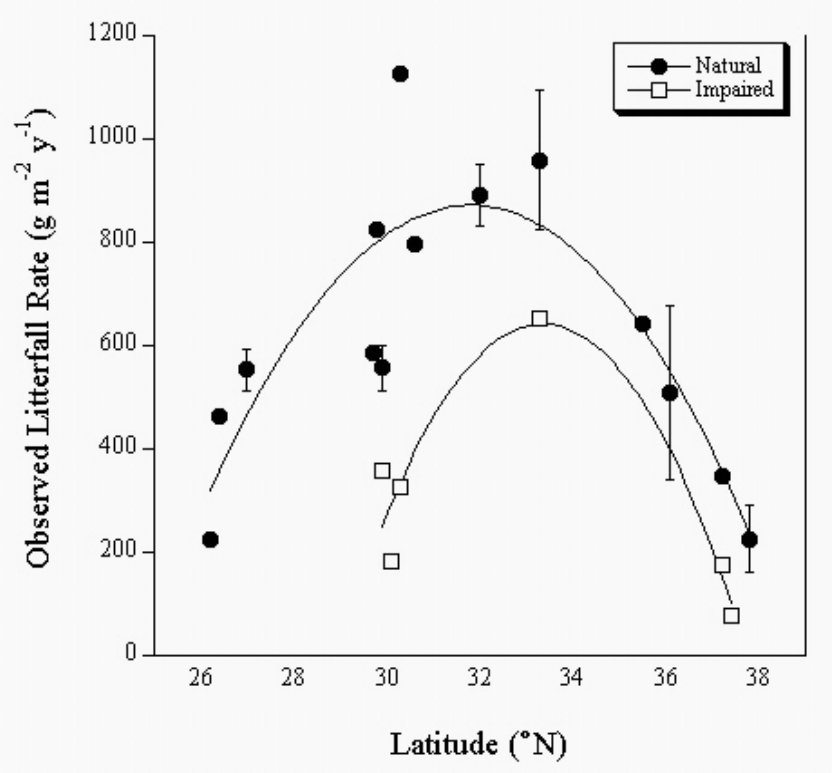

Figure 1. Total litterfall rates measured in baldcypress (Taxodium distichum) swamps at various latitudes. Swamps with natural $(\bullet)$ and impaired $(\bullet)$ hydrology are plotted separately (Middleton and McKee, 2004). A second-order polynomial curve was fitted to the data (SAS JMP, 2003). Reprinted by permission of Global Ecology and Biogeography.

\footnotetext{
${ }^{1}$ U.S. Geological Survey, National Wetlands Research Center, 700 Cajundome Boulevard, Lafayette, LA 70506
} 
A modest climate change of 20 percent to 30 percent climate drying by 2030 and 2060, respectively in the southeastern United States, is predicted by the GCMI model (Hengeveld, 2000), and climate drying would have negative effects on the ability of swamp species to regenerate themselves.

Climate change may have severe effects on the ability of baldcypress swamp species to regenerate themselves. At the present time, many more viable seeds of baldcypress trees are found in the seed banks from the northern part of the range, either because seed production rates are higher or because seeds may be stored for somewhat longer periods of time in Tennessee and northward (e.g., Cache River, Ill., and Reelfoot Lake, Tenn; Middleton unpublished data). A reduction in precipitation may reduce the seed bank density of important herbaceous swamp species including Aster sp., Cyperus erythrorhizos, Eupatorium sp., Fimbristylis miliacea, Hottonia inflata, Mitreola petiolata, and Phyla lanceolata to unsustainable levels (Middleton unpublished data). Recruitment of many species is dependent on moisture conditions in the soil (Middleton, 1999, 2003), and seed density in the seed bank is an important component of the regeneration process. Changes in climate patterns could have a big impact on the process of swamp forest regeneration.

The effects of climate drying may cause problems for managers, particularly because certain rare species may become less common and certain undesirable species may become more common in the seed bank. For example, $H$. inflata is a rare species in the northern part of its swamp range and a State-listed species in many localities, and climate drying reduces its seed density in the soil. Of special concern is that climate drying may increase the seed bank density of buttonbush (Cephalanthus occidentalis), a native but undesirable species among wildlife and fisheries managers. Climate change will shift management priorities for managers.

Managers of baldcypress swamps at the southern extreme of their range are likely to face the loss of biodiversity in these swamps as species become unable to deal with predicted hotter and drier conditions through regional habitat reduction and invasive species intrusion. Coastal saltwater intrusion is likely in coastal swamps if sea levels rise, and this situation poses particular problems to managers. Managers in the middle of the baldcypress swamp range may face a partial loss of habitat via declining production and loss of biodiversity.

Managers should be prepared for potential changes caused by climate change in refuges so that they can proactively address the situation. If climates become warmer and drier in the Southeast in the future, species may not be able to move northward fast enough to avoid local extirpation because aquatic seeds disperse southward on rivers (fig. 2; Middleton, 2003). Managers involved in restoration projects outside of the current range of baldcypress swamps might want to reconsider which species they use, depending on which species are best suited for the climate. In regions at the edge of the baldcypress swamp range, species from just outside of the current range might grow better in restoration plots. For example, managers in south-central Illinois could try planting some plots with species from baldcypress swamps, which are outside of the range currently considered. Similarly, managers in Texas might plant species from farther southwest. The idea of using species for restoration that are best suited to the climate is not tested in the field; however, theoretical studies support such practices (Middleton and McKee 2004). If climate change is a reality, then the situation should become apparent via changing patterns of production, regeneration, and species distribution. 


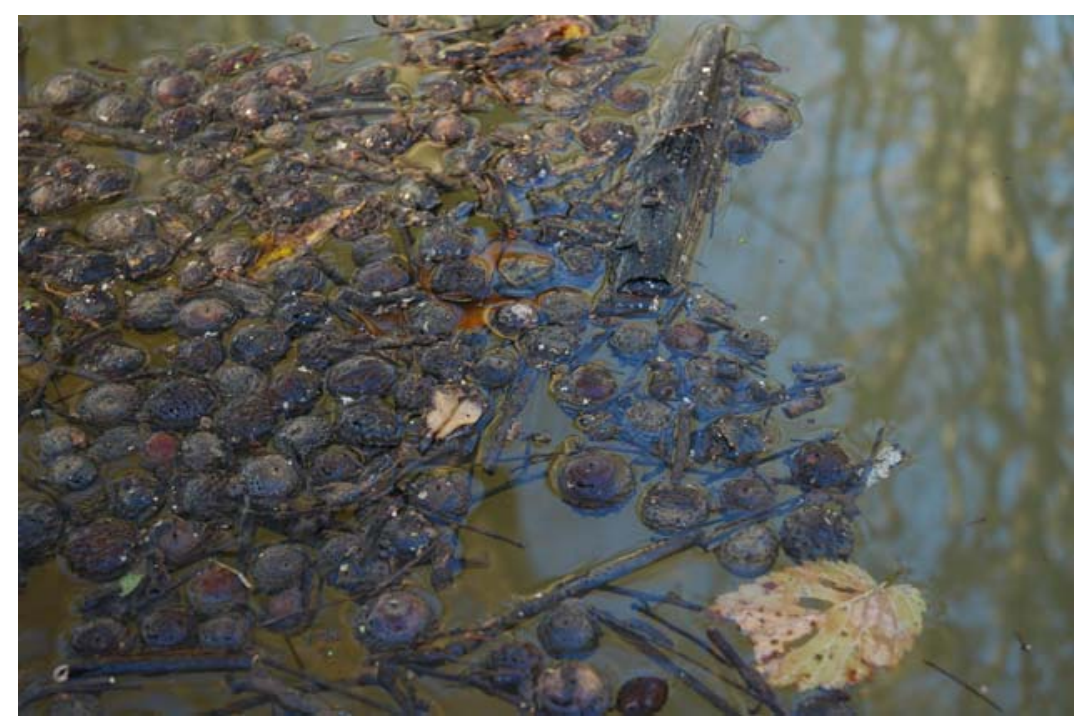

Figure 2. Overcup oak (Quercus lyrata) dispersing in water. Seed dispersal and germination may be hampered by climate drying.

\section{References Cited}

Crumpacker, D.W., Box, E.O., and Hardin, E.D., 2001, Temperate-subtropical transition areas for native woody plant species in Florida, U.S.A.: present locations, predicted changes under climatic warming, and implications for conservation: Natural Areas Journal, v. 21, p. 136 - 148.

Hengeveld, H., 2000, Projections for Canada's climate future. Climate change digest CCD 00-01: Downsview, Ontario, Environment Canada, Meteorological Service of Canada, 27 p.

Middleton, B.A., 1999, Wetland restoration, flood pulsing and disturbance dynamics: New York, New York, John Wiley and Sons, 400 p.

Middleton, B.A., 2003, Soil seed banks and the potential restoration of forested wetlands after farming: Journal of Applied Ecology, v. 40, p. 1025 - 1034.

Middleton, B.A., and McKee, K.L., 2004, Use of a latitudinal gradient in bald cypress production to examine physiological controls on biotic boundaries and potential responses to environmental change: Global Ecology and Biogeography, v. 13, p. 247 258.

SAS JMP, 2003, JMP statistics and graphics guide. Version 5.0.1: Cary, N.C., Statistical Analysis System, 634 p. 